\title{
Targeted admission as a mechanism for HR formation in the agro-industrial complex
}

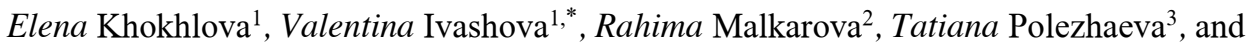 \\ Andrey Solovyev ${ }^{4}$ \\ ${ }^{1}$ Stavropol State Agrarian University, 12, Zootechnicheskiy Lane, Stavropol, 355017, Russia \\ ${ }^{2}$ Kabardino-Balkarian State University named after H.M. Berbekov, 173, Chernyshevskaya Street, \\ Nalchik, 360004, Russia \\ ${ }^{3}$ Russian State Agrarian University - Moscow Timiryazev Agricultural Academy, 49, \\ Timiryazevskaya Street, Moscow, 127550, Russia \\ ${ }^{4}$ Moscow State Pedagogical University, 1, Malaya Pirogovskaya Street, Moscow, 119991, Russia
}

\begin{abstract}
The article describes the targeted admission in the system of higher agricultural education in Russia as an institutional mechanism for the reproduction of the personnel potential of the country's agro-industrial complex. The problem of reproduction of specialists in the agrarian sector has a deep contradiction and is characteristic not only for Russia or its individual regions, but at the global level. The empirical part of the study was carried out by the method of statistical analysis of data on the quality of targeted admission in the system of higher agricultural education in Russia in 2020. The article contains the characteristic of targeted admission in the system of agricultural education as an institutional mechanism for the reproduction of the personnel potential of the industry: all agricultural universities comply with the requirements of the legislation of the Russian Federation, carrying out the admission of applicants for targeted training; customers are local authorities, state authorities of the regions, state enterprises; employers are mainly business entities of the agro-industrial complex; for the period 2018-2020 the admission of applicants to targeted training in agricultural universities decreased by $37.4 \%$ due to the reduction in the targeted figures for general admission and low interest of applicants; for training programs for highly qualified personnel, the quotas for the study period were filled from $12.5 \%$ to $22.5 \%$. Conclusion: the targeted method in the system of higher agricultural education of the Russian Federation as an institutional mechanism does not fulfil the assigned tasks and requires improvement.
\end{abstract}

\section{Introduction}

The problem of reproduction of specialists in the agrarian sphere has a deep contradiction and is characteristic not only for Russia or its individual regions, but also on a global scale. This contradiction is associated with the dysfunctional labour markets in the field of agro-

* Corresponding author: vivashov@mail.ru 
industrial production and agrarian education and with the growing depopulation of rural areas, undermining the sustainable development of entire agricultural regions. The issues of the direction and scaling of the reproduction process of social and professional groups, in particular of agricultural specialists, are especially aggravated during the period of significant social, economic, industrial and technological transformations. Currently, such transformations include the introduction of digital technologies, artificial intelligence, the uncertainty of socio-economic transformations, increasing technological and environmental risks in agricultural production, and others. All this determines the relevance of the research topic.

The process of reproduction of specialists from agricultural enterprises plays an important role in the sustainable development of rural areas. Specialists of agricultural enterprises (agronomists, veterinarians, livestock specialists, mechanical engineers, electrical engineers, economists, accountants) are a special social and professional group in the rural community. It has a higher level of education in comparison with the general values of the population in rural areas; traditionally high social status and influence on public opinion on key social, economic, and political issues of our time. Experts of agricultural enterprises have a high innovative and socio-cultural potential, contributing to the promotion of innovations in production processes, updating the social and cultural practices of the population of rural areas. In general, the social and professional group of specialists from agricultural enterprises can be attributed to one of the key stakeholders in rural areas, the reproduction of which should meet the national interests of territorial and food security, both in individual regions and in Russia as a whole.

Topical issues of the study of reproduction processes, which are interdisciplinary in nature, are the object of research and scientific discussion of modern authors of scientific publications. The issue of reproduction of a socio-professional group is a complex problem, since it affects a number of socio-economic systems of society: economic reproduction, when it comes to the resumption of production processes; socio-economic - the reproduction of economic relations, material wealth, staffing; social - reproduction of a complex of social relations in the existing institutional system (continuity and renewal of values, norms, social structure, processes and institutions).

The article of the authors A. Bolívar-Cruz, M. Fernández-Monroy, I. Galván-Sánchez presents an interesting approach to the analysis of the interaction between the industrial sphere and university education [1]. It consists in the development of communications that ensure active technological cooperation. In the context of our research it is essential to have the presence of subsystem of communications between agricultural production and higher agricultural education (in the model of the reproduction process of a social and professional group). Accordingly, the targeted admission for training specialists in the agricultural sector as an institutional mechanism for reproduction should provide a regulatory and legal basis for these communications, suggesting a targeted vector of territorial development of production and monitoring indicators of its achievement.

The study by M. Sponte shows the relationship between the economic reproduction process in agricultural production and the reproduction of a complex of social relations in the existing institutional system: continuity and renewal of values, norms, social structure, processes [2]. An important aspect for our study is that: it is young farmers who bring technological innovations into the production process and the system of social relations of the rural community. Accordingly, targeted management of the influx of young agricultural specialists has a positive effect on the entire range of reproduction processes in rural areas, giving them a new quality.

New characteristics of the reproduction of the production process in the agricultural sector lead to the need to improve the social and professional reproduction processes of the personnel potential of the industry. Researchers K. Otsuka, M. Ali emphasize the relevance 
of this relationship in their study "Strategy for the development of agro-based clusters" [3]. They emphasize that in the transition from agricultural production to its deep processing in accordance with the requirements of the market for its standardization, it is important not only to ensure the technological process. For the success of the reproduction process of modern agricultural technologies, it is necessary to cover the improvement of employees of agricultural and processing enterprises through their training, including management personnel. In addition, it is needed to organize professional groups of stakeholders to promote innovation, the introduction of an appropriate regulatory framework for innovation. For our study, it is important to conclude that it is necessary to organize support for institutional changes in the reproduction process in the agro-industrial complex, both from the participants in social and professional relations and the state.

An interesting approach to the promotion of modern knowledge and innovations in the agricultural sector is proposed by the scientist C. Ragasa; it consists in using farmers opinion leaders of the social and professional community - as a driving force for this process [4]. Based on the statistical analysis of data from surveys of the farming community, opinion leaders of this community, important conclusions were drawn about the effectiveness of the approach. Institutional mechanisms for innovation processes in the agrarian sector, such as consulting services and non-profit organizations, did not lead to the desired effect. At the same time, the use of opinion leaders of the farming community as moderators of the innovation of the reproduction process led to the improvement of agricultural practices in the organization of training for farmers. It can be concluded that the institute of agrarian education is highly important in the technological and social reproduction process of the agrarian sphere.

Institutional mechanisms that ensure stable reproduction processes in the agricultural sector have become a research issue in the study of the capabilities of public institutions for risk management in agriculture [5]. On the basis of a questionnaire survey of regional officials, areas were identified for improving the existing institutional mechanisms for regulating the availability of information to producers of agricultural products on the climatic characteristics of the region, training and consulting, financial and technological resources of expanded reproduction in the agricultural sector. The authors of the study associate the improvement of the reproduction process with the development of financial potential and human resources. Thus, we see the role of state regulation of sustainable development of the agricultural sector and the factors that ensure this process: institutional mechanisms for the reproduction of financial resources and human resources of the industry $[6,7,8]$.

Thus, the conclusions confirm the relevance of innovative approaches to improving the institutional mechanisms of reproduction of the social and professional group of specialists in the agricultural sector and farmers $[9,10,11]$. It is a significant factor in the sustainable development of rural areas and agricultural enterprises, as well as financial support and technical innovations in this area $[12,13,14]$.

Improvement of targeted admission in the system of higher agricultural education is an important tool for reproducing the personnel potential of the industry and innovations of the institutional mechanism; it plays an important role in ensuring the territorial and food security of Russia.

\section{Materials and methods}

The empirical part of the study was carried out by the method of statistical analysis of data on the quality of targeted admission in the system of higher agricultural education in Russia, 2020. 
The institutional mechanism for organizing and implementing targeted training in educational programs of higher education is regulated by the Decree of the Government of the Russian Federation of March 21, 2019 No. 302 "On targeted training in educational programs of secondary vocational and higher education and invalidation of the Decree of the Government of the Russian Federation No. 1076 of November 27, 2013", By the Order of the Government of the Russian Federation of March 4, 2020 No. 514-r in accordance with the established quotas at the expense of budgetary allocations from the federal budget. A statistical analysis of the results of admission of applicants on the terms of targeted admission to universities subordinated to the Ministry of Agriculture of the Russian Federation was carried out for 2018-2020 and segmentation by EGSP.

\section{Results}

For 2018-2020 admission of applicants for targeted training at agricultural universities decreased from 3475 people up to 2164 people (by 37.4\%). In 2020, this figure was 2164 people or $33.3 \%$ of the planned targeted admission, in $2019-1634$ people. $(27.6 \%)$, in 2018 this figure was 3475 people $(38.8 \%)$. The share of targeted admission in total admission to universities subordinated to the Ministry of Agriculture of the Russian Federation in 2020 was $4.1 \%$, in $2019-2.0 \%$, in $2018-2.8 \%$. The data are presented in Table 1.

Table 1. Results of targeted admission to universities subordinated to the Ministry of Agriculture of the Russian Federation for 2018-2020.

\begin{tabular}{|c|l|c|c|c|}
\hline № & \multicolumn{1}{|c|}{ Index } & $\mathbf{2 0 1 8}$ & $\mathbf{2 0 1 9}$ & $\mathbf{2 0 2 0}$ \\
\hline 1 & General admission, people & 85053 & 83408 & 78280 \\
\hline 2 & Targeted admission plan, people & 8960 & 5928 & 6494 \\
\hline 3 & The fact of the targeted admission, people. & 3475 & 1634 & 2164 \\
\hline 4 & $\begin{array}{l}\text { Relative share of the targeted admission plan } \\
\text { fulfilment, } \%\end{array}$ & 38.8 & 27.6 & 33.3 \\
\hline 5 & Relative share of targeted intake in total intake, $\%$ & 4.1 & 2.0 & 2.8 \\
\hline
\end{tabular}

Implementation of the targeted admission plan by education levels for 2018-2020 is presented in Table 2.

Table 2. Implementation of the targeted admission plan by levels of education in universities subordinated to the Ministry of Agriculture of the Russian Federation for 2018-2020.

\begin{tabular}{|l|c|c|c|c|c|c|}
\hline \multirow{2}{*}{ Levels of education } & \multicolumn{2}{|c|}{2018} & \multicolumn{2}{c|}{2019} & \multicolumn{2}{c|}{2020} \\
\cline { 2 - 7 } & Plan & Fact & Plan & Fact & Plan & Fact \\
\hline $\begin{array}{l}\text { Admitted students based on the results of } \\
\text { targeted admission for 1 course in } \\
\text { undergraduate and specialty programs, people }\end{array}$ & 7993 & $\begin{array}{c}3234 \\
(40.5 \%)\end{array}$ & 4659 & $\begin{array}{c}1502 \\
(32.2 \%)\end{array}$ & 5063 & $\begin{array}{c}1939 \\
(38.3 \%)\end{array}$ \\
\hline $\begin{array}{l}\text { Admitted students based on the results of } \\
\text { targeted admission for 1 course in Master's } \\
\text { programs, people }\end{array}$ & 935 & 230 & 1183 & 118 & 1258 & 174 \\
$(24.6 \%)$ & $(10 \%)$ & & & \\
\hline $\begin{array}{l}\text { Admitted students based on the results of } \\
\text { targeted admission for 1 year in postgraduate } \\
\text { programs, people }\end{array}$ & 24 & $\begin{array}{c}3 \\
(12.5 \%)\end{array}$ & 105 & $\begin{array}{c}11 \\
(10.5 \%)\end{array}$ & 201 & $\begin{array}{c}46 \\
(22.9 \%)\end{array}$ \\
\hline $\begin{array}{l}\text { Admitted students based on the results of } \\
\text { targeted admission for 1 course in VSE } \\
\text { programs, people }\end{array}$ & 8 & $\begin{array}{c}8 \\
(100 \%)\end{array}$ & 3 & $\begin{array}{c}3 \\
(100 \%)\end{array}$ & 5 & $\begin{array}{c}5 \\
(100 \%)\end{array}$ \\
\hline $\begin{array}{l}\text { TOTAL by forms of education, people: } \\
\text { TOTAm }\end{array}$ & 8960 & $\begin{array}{c}3475 \\
(38.8 \%)\end{array}$ & 5950 & $\begin{array}{c}1634 \\
(27.6 \%)\end{array}$ & 6517 & $\begin{array}{c}2164 \\
(33.3 \%)\end{array}$ \\
\hline
\end{tabular}




\section{Discussion}

Fulfilment of the admission plan for undergraduate and specialty programs for the analyzed period decreased from $40.5 \%$ to $38.3 \%$. For Master's programs it decreased from $24.6 \%$ to $13.8 \%$. While graduate programs have seen 10.4 percentage point increasing in targeted admission plan completion rates.

In the context of enlarged groups of specialties and profiles (EGSP) in 2018-2020 targeted admission to agricultural universities was carried out at 21 EGSP (see Table 3). Enrolment on the basis of admission to enlarged groups is of a versatile nature, due to the specifics of the university, but the prevailing EGSP are invariably: 35.00.00 Agriculture, Forestry and Fisheries, 36.00.00 Veterinary Medicine and Animal Husbandry, 23.00.00 Equipment and Technologies of Land Transport, 21.00 .00 Applied Geology, Mining, Oil and Gas Business, Geodesy, 38.00.00 Economics and Management, 13.00.00 Electricity and Heat Power Engineering.

In 2020, on the basis of targeted admission to universities subordinated to the Ministry of Agriculture of the Russian Federation, 2,164 people were admitted; it is $33.3 \%$ of the targeted admission plan. Compared to 2018, this figure increased by 530 people.

Out of 2164 people admitted on the basis of targeted admission we see that: 1939 people (38.3\% of the admission plan) - undergraduate and specialist programs; Master's programs -174 people ( $13.8 \%$ of the admission plan); postgraduate programs - 46 people ( $22.9 \%$ of the admission plan); VSE programs -8 people ( $100 \%$ of the admission plan).

The distribution of applicants on the terms of targeted admission by forms of study in 2020 is as follows: 1734 people $(80.1 \%)$ got into the full-time education; 19 people $(0.9 \%)$ got into the part-time form of education; 411 people (19\%) got into the correspondence course.

The largest number of applicants admitted on the basis of targeted admission in 2020 was for the following EGSP: 35.00.00 - Agriculture, Forestry and Fisheries - 971 people and 36.00.00 - Veterinary and Animal Science - 686 people. In general, 1657 people got into these two EGSP, which amounted to $76.7 \%$ of the total number of applicants who were admitted on the basis of targeted admission in 2020 .

Analysis of the data on the implementation of the targeted admission plan in 2020 in 54 agricultural universities shows a high level of heterogeneity both in terms of the magnitude of the indicators of the implementation of the plan and the intensity of their change in dynamics. So, the targeted admission plan in 2020 was fulfilled: from $50 \%$ to $100 \%-16$ agricultural universities, from $20 \%$ to $49 \%$ - 19 agricultural universities, from $1 \%$ to $19 \%-$ 19 agricultural universities.

\section{Conclusions}

The analysis made it possible to characterize targeted admission in the system of agricultural education as an institutional mechanism for the reproduction of the personnel potential of the industry.

It has been established that all agricultural universities comply with the requirements of the legislation by accepting applicants for targeted training. Targeted training is carried out on the basis of an agreement on targeted training concluded between a citizen entering training in an educational program and a federal state body, a state authority of a constituent entity of the Russian Federation, a local government body, a legal entity or an individual entrepreneur.

In the process of studying the materials, it was found that the customers are, as a rule, local governments, state authorities of the regions, less often state enterprises. Employers, 
according to concluded agreements, are mainly economic entities of the agro-industrial complex - organizations engaged in the production of agricultural products, as well as their processing.

For 2018-2020 admission of applicants for targeted training in agricultural universities decreased from 3475 to 2164 people (by $37.4 \%$ ). This reduction is due to objective reasons: there has been a reduction in the admission quotas allocated to universities, from which quotas for targeted education are allocated; the reluctance of applicants to take on obligations arising from the concluded agreements on targeted training if they have the opportunity of real admission through a general competition for budget places.

As a result of the study, it was revealed that admission to targeted training is carried out only within the framework of quotas allocated from the admission control figures at the expense of budget allocations from the federal budget, since there is no funding for universities from regional and local budgets.

According to the current legislation, educational organizations are also required to allocate targeted admission quotas for postgraduate and graduate programs. Studies have shown that in the overwhelming majority of universities, there was no admission of applicants allocated for targeted admission quotas for training programs for highly qualified personnel; in general, quotas for the study period were filled from 12.5 to $22.5 \%$. As a positive moment, we note the growth of the number of admitted graduate students from 3 to 45 people.

From January 1, 2021, the Decree of the Government of the Russian Federation of October 13, 2020 No. 1681 "On targeted training in educational programs of secondary vocational and higher education" will come into force and will be valid until January 1, 2027. This Resolution is aimed at improving the institutional mechanism of targeted admission and will have a positive effect on the reproduction processes of the personnel potential of the agro-industrial complex of Russia. It establishes responsibility for educational organizations that take applicants for targeted training in the form of reimbursement of the costs of training a "targeted" in case of refusal of employment, etc. Currently, these norms did not apply to educational organizations. Another direction of improving the institutional mechanism of targeted admission will be the coordination of the number of budget places for targeted training allocated to regions with the state authorities of the subjects.

The development of an innovative model of the regional process of reproduction of specialists of agricultural enterprises on the example of a number of constituent entities of the Russian Federation will constitute an additional toolkit in information and analytical support of management at the regional level and is an urgent direction of research development.

\section{References}

1. A. Bolívar-Cruz, M. Fernández-Monroy, I. Galván-Sánchez, Journal of Technology Management and Innovation 12 (3) (2017)

2. M. Sponte, Quality - Access to Success 15 (1) (2014)

3. K. Otsuka, M. Ali, World Development Perspectives 20 (2020)

4. A. Ragasa, Land Use Policy 99 (2020)

5. N.A. Khan, Q. Gao, M. Abid, Scientific Reports 10 (1) (2020)

6. M. Braito, H. Leonhardt, M. Penker, G. Thaler, C.G. Flint, Land Use Policy 99 (2020)

7. A. Pratiwi, A. Suzuki, Agricultural and Food Economics 8 (1) (2020) 
8. A. Zakaria, S.B. Azumah, M. Appiah-Twumasi, G. Dagunga, Technology in Society 63 (2020)

9. V.N. Goncharov, A.M. Erokhin, V.A. Ivashova, O.U. Kolosova, R.V. Chvalun, V.A. Berkovsky, IOP Conference Series: Earth and Environmental Science 422 (1) (2020)

10. P.M. Gichohi, Information Development 36 (4) (2020)

11. T. Russell, J. Breen, M. Gorman, K. Heanue, Journal of Agricultural Education and Extension 26 (5) (2020)

12. A. Kpienbaareh, R.B. Kerr, I. Luginaah, L. Dakishoni, L. Shumba, Land 9 (10) (2020)

13. I.S. Baklanov, O.A. Baklanova, A.M. Erokhin, N.N. Ponarina, G.A. Akopyan, TarihKültürveSanatAraştırmaları 7 (2) (2018)

14. V.N. Goncharov, A.M. Erokhin, V.A. Ivashova, L.A. Tronina, O.N. Kamalova, IOP Conference Series: Earth and Environmental Science 422 (1) (2020) 